more or less co-extensive with the present coalfields, receive no support from Renier's work.

In contrast with the uniformity of the floors of the coal seams, the roofs yield extremely varied faunas and floras. These have been examined and recorded with great precision. Renier quotes approvingly the words of Crépin, who laid down two rules for palæontologists working on the coal measures so long ago as 1878. Palæontologists, he advised, should never confine their researches to material collected from the rubbish tips of collieries, but should themselves descend the mines and study the Carboniferous vegetation in situ ; further, they ought not to leave the collecting exclusively to workmen and others ignorant of the science, but to undertake some of the labours themselves.

The neglect of this advice-not only in Belgiumled for many years to serious errors in regard to the palæontology of the coal measures. Thus, Prof. Renier shows that certain palæontologists who have studied the coal measures of Belgium since Crépin's time based their conclusions almost entirely on museum collections, and decided that the flora was uniform in character from top to bottom of the sequence; recent work, on the other hand, based on the actual examination of each horizon, has made it clear that distinct floras can be recognised and used both in the identification of seams and in the correlation of the coal measures over western Europe.

Prof. Pruvost's account of the non-marine faunas makes a fitting sequel to his monumental work on the faunas of the coal measures of the north of France. A beautiful series of plates is devoted chiefly to the fossil insects and other arthropods and to the fishes. A number of remarkable fossils is described, and this part of the memoir will be indispensable to all students of coal measure palæontology. It is much to be regretted that no illustrations of any of the Mollusca are included (except in relation to their supposed borings); the Mollusca are much more frequent than other fossil animals at most horizons, and Pruvost relies on them to a great extent in his correlation.

Pruvost is not prepared, however, to accept any of the refinements in nomenclature which have been made in recent years. To a large extent he has followed the late Dr. Wheelton Hind, who was very conservative (and sometimes, unfortunately, rather inaccurate) in his interpretation of these species. But whereas even the latter was willing to recognise some twenty-five species of non-marine lamellibranchs in the coal measures of Belgium, Pruvost admits no more than twenty. In his 'lumping' of species he places Anthracomya librata Wright as a synonym of Carbonicola similis Brown, and Naiadites elongata Hind as a synonym of Anthracomya phillipss Will. It is probable that his discrimination of the faunas is much more precise than the nomenclature which he uses, but his method must make it difficult for other palaeontologists to make full use of his labours.
A. E. Trumman.

\title{
Dyestuffs and Enzymes.
}

$M^{\prime}$

ANY dyes and related compounds have a specific toxic effect on certain micro-organisms which has been utilised in the treatment of the diseases caused by them. The mode of action of the dyestuff is not known, but it is probable that it poisons some particular system in the cell, without which the latter cannot carry on its metabolic activities.

Some recent researches by J.H. Quastel on the action of dyes upon enzymes may throw light not only on the nature of the toxic effect, but also on the constitution of the enzymes employed (Biochem. Jour., vol. 25, p. 629 ; 1931 (with A. H. M. Wheatley); and ibid., vol. 25 , pp. 898 and 1121 ; 1931). In the first paper it was found that basic, but not acid, dyes inhibited the oxygen uptake by $B$. Coli in the presence of glucose, lactate, succinate, and formate. The degrees of inhibition varied both with the dye and the substrate used, so that the effect could not be due to a general lethal action. Since it is the basic dyes which are active, it appears that the cell dehydrogenases are essentially acidic in character; but basicity is not the only factor in toxicity, since the basic Bismarck brown has little action. The inhibitory action of the dye was less marked in phosphate than in veronal buffer. Similar results were obtained with muscle enzymes, but no inhibition was observed with any dye when brain tissue was used, probably because the dye failed to reach the enzyme.

In the second paper, the behaviour of fumarase from micro-organisms or from brain or red-blood cells was studied. This enzyme converts fumarate to $l$ malate, which can be estimated polarimetrically. It was found that both acid and basic dyes were toxic, but a marked specificity was apparent; of the former, the Congo red series was the most toxic, of the latter, the triphenylmethane series. It was also observed that fumarate combines with its enzyme and prevents the combination, and hence the toxic action, of both acid and basic dyes; that proteins exert a protective action, and that the protective action of phosphates is less than in the case of the dehydrogenases.

The most recent experiments have been carried out with certain naphthylaminedisulphonic acids and fumarase, after observing that trypan red and Bayer 205, like Congo red and trypan blue, are toxic. None of the six acids tested were toxic, nor were their first $s$-carbamide derivatives. The second and especially the third $s$-carbamide derivatives were, however, very toxic, that is, the $s$-carbamides of $m$-aminobenzoylnaphthylaminedisulphonic acid and of $m^{\prime}$-aminobenzoyl - $m$ - aminobenzoylnaphthylamine - disulphonic acid. The importance of this observation lies in the fact that there is a definite, though not strict, parallelism between the toxic action of these carbamides on fumarase and their trypanocidal potency, as determined by Balaban and King. It is possible that this method of investigating the toxicity of dyestuffs on enzymes may prove suitable for preliminary tests in the preparation of compounds likely to be of chemotherapeutic value.

\section{Carbonisation of Coal.}

CREAT expectations have been placed upon coal carbonisation at low temperatures as a source of motor spirit. Fuel Research Technical Paper No. 34 (H.M.S.O., 6d. net), on the "Light Spirits from the Low Temperature Carbonisation of Coal", shows that the experience with benzole production cannot be directly transferred to low temperature products.
The proportion of tar acids and unsaturated compounds is higher, necessitating greater consumption of chemicals in refining. The refined products were found by actual tests in petrol engines to be good motor fuels at least equal, when fresh, to commercial petrol. They still contained considerable quantities of unsaturated compounds which were liable to polymerise

No. 3244, VoL. 129] 